Dr PHILIP CASS is reviews editor of Pacific Journalism Review.

\section{The revolution still isn't here}

Journalism as Activism, by Adrienne Russell. Cambridge: Polity Press, 2016, 200 pages. ISBN 978-0-745-6712-6-0

\section{N 1845 Marx wrote:}

The class which has the means of material production has control at the same time over the means of mental production so that... generally speaking, the ideas of those who lack the means of mental production are subject to it... as they rule as a class and determine the extent and compass of an epoch, it is self-evident that they... regulate the production and distribution of the ideas of their age; Thus their ideas are the ruling ideas of the epoch.

The debate over who controls our thoughts and modes of thinking, how this can be challenged, by whom and by what means has occupied generations of writers and activists. In each generation a vision has been raised of a vanguard leading people forward, using the media to spread coherent and energising messages of change.

There are echoes of these ideas in Russell's new book, in which she envisions a cadre of online activists, journalists and technologists acting as the vanguard of some kind of radical change in the way we lead our lives through the exploitation of the internet. She sees them as having

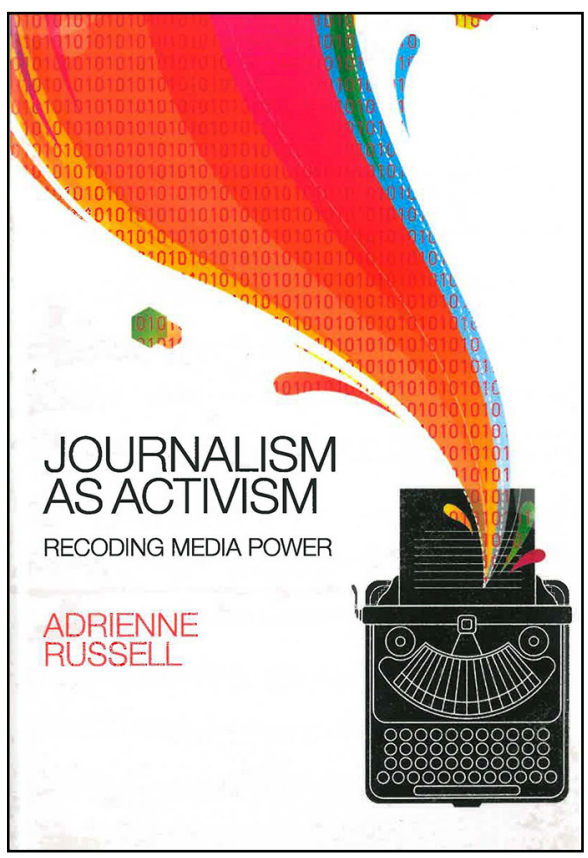

secured the means of both production and distribution and thus, potentially, of challenging the ruling ideas of the dominant class.

Perversely, however, she also notes that many of those who are presumably in the vanguard of online social change are mimicking the practices of the giant corporations and institutions they presumably aim to overthrow, even collaborating with them on certain projects.

She sees journalists as being an essential part of this liberating mix, but her ideas of what constitutes journalism - and who is entitled to call themselves journalists-reflect the view that anybody can be a journalist. This is coupled with the notion that as long as the internet functions as an online agora, a Habermasian space that allows for the free flow of ideas 
and the harnessing of technology to the struggle for social change, then anybody should be able to contribute to the discussion.

Early in the book she discusses the Occupy Movement and the way in which some of its participants in New York began to get their stories into the media, as protesters who somehow also wound up being regarded as reporters. The problem is that the blurring of lines between participants, reporters, journalists and hacktivists that Russell so celebrates, and which she sees as essential to social change, is actually inimical to its success.

The Occupy Movements fizzled out precisely because it had no defined centre, no plan, no manifesto and no leader who could really get across any message beyond the fact that they were, quite rightly, but inarticulately, angry.

It is all very well to declare that the technological vanguard has let the people write the story from within, or that everybody is now a journalist, but unless there is enough structure to hold ideas in place, everything falls apart; the centre does not hold and Donald Trump is let loose upon the world.

\section{Reference}

Marx, Karl (1845). The illusion of the epoch. In The German ideology. Retrieved from www.marxists.org/archive/marx/ works/1845/german-ideology/ch01b. $\mathrm{htm}$
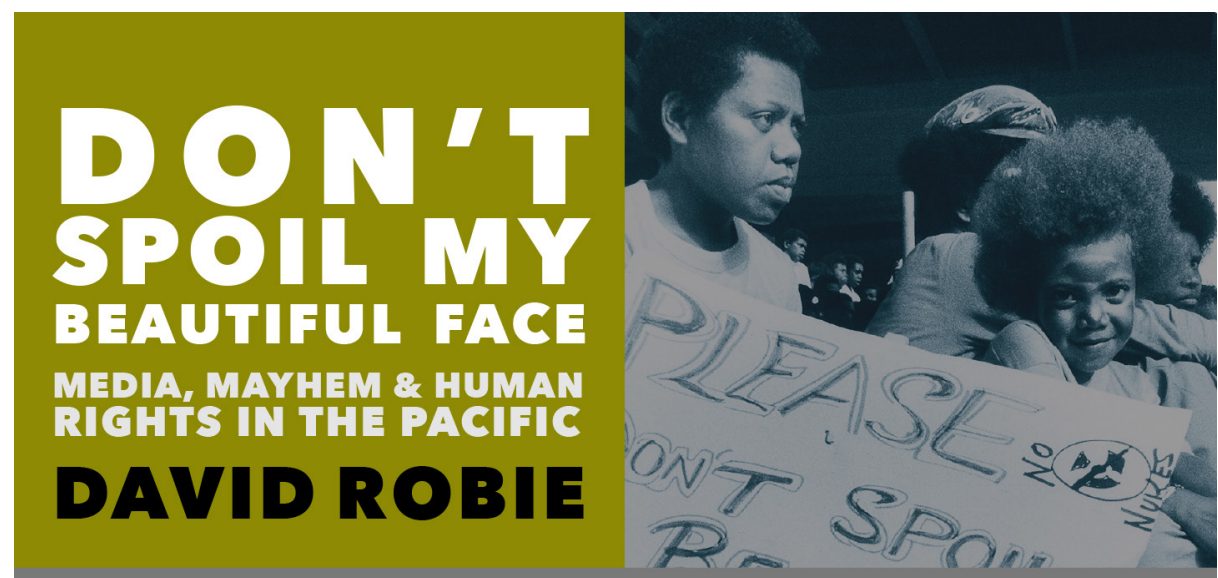

"This is an extraordinary 'secret history' of a vast region of the world of which David Robie has been a rare expert witness. What makes this epic work so timely is that it allows us to understand the Asia-Pacific at a time of renewed cold war ambitions and dangers." - John Pilger

little island press • ISBN 978-1-877484-25-4 • www.littleisland.co.nz 